\title{
Dose-dependent suppression of tolaasin-induced hemolysis by gadolinium ion
}

\author{
Jeong-Hoon Huh ${ }^{1,2}$ (I) $\cdot$ Yeong-Bae Yun ${ }^{1,2}$ (]) $\cdot$ Young-Kee Kim $^{1}$ (])

\section{가돌리니움 이온에 의한 톨라신 용혈활성의 농도의존적 억제}

허정훈 ${ }^{1,2} \cdot$ 윤영 배 $^{1,2} \cdot$ 김영기 $^{1}$

Received: 24 September 2021 / Accepted: 9 October 2021 / Published Online: 31 December 2021

(C) The Korean Society for Applied Biological Chemistry 2021

\begin{abstract}
Brown blotch disease of oyster mushrooms is caused by tolaasin and its analog peptide toxins which are produced by Pseudomonas tolaasii. Tolaasin peptides form pores in the plasma membrane and destroy the fruiting body structure of mushroom. Lysis of red blood cells, hemolysis, can be occurred by cytotoxic activity of tolaasin. The hemolytic activity of tolaasin is inhibited by metal ions, such as $\mathrm{Zn}^{2+}$ and $\mathrm{Ni}^{2+}$. When Gadolinium ion was added, a biphasic effect was observed on tolaasin-induced hemolysis, an increase in hemolysis at submillimolar concentrations and an inhibition at millimolar concentrations. The mechanism of gadolinium ion-induced inhibition of tolaasin activity may not be similar to those of the inhibitions by other metal ions. Since gadolinium ion has been reported to change a lateral pressure of lipid membrane by binding to the negative charges of membrane lipids, it may not directly work on the tolaasin channel gating, but rather decrease the stability of tolaasin channel by increasing firmness of membrane.
\end{abstract}

Keywords Gadolinium - Membrane rigidity · Pseudomonas tolaasii $\cdot$ Tolaasin

Young-Kee Kim $(\triangle)$

E-mail: ykkim10@cbnu.ac.kr

${ }^{1}$ Department of Environmental and Biological Chemistry, Chungbuk National University, Cheongju, Chungbuk 28644, Republic of Korea

${ }^{2}$ Forest Medicinal Resources Research Center, National Institute of Forest Science, Yeongju, Gyeongbuk 36040, Republic of Korea

This is an Open Access article distributed under the terms of the Creative Commons Attribution Non-Commercial License (http://creativecommons. org/licenses/by-nc/3.0/) which permits unrestricted non-commercial use, distribution, and reproduction in any medium, provided the original work is properly cited.
서 론

다양한 버섯 중에서 느타리버섯은 국내에서 상업적으로 가장 활 발히 재배되고 유통되는 버섯으로, 주요 영양성분은 물론 항암 및 항균 물질을 포함하고 있어 국제적으로도 많은 소비가 이루 어지고 있다[1]. 느타리버섯은 전문적인 농가에서 재배되나, 버 섯의 자실체 표면에 갈색 반점이 생성되는 갈반병의 잦은 발병 으로 농가는 큰 피해를 입고 있다. 이 병은 한번 발생하면 재 배단지 전체에 빠르게 퍼질 수 있어 버섯 재배를 어렵게 하는 가장 큰 원인중의 하나이다[2,3]. 갈반병은 세포막을 파괴하는 세균독소인 톨라신(tolaasin)에 의해 발생하며, 톨라신은 Pseudomonas tolaasii 병원균이 합성하여 분비하는 $1,985 \mathrm{Da}$ 의 lipodepsipeptide로, 펩티드 단량체 분자가 중합체를 형성하며 버 섯의 표면 세포막에 pore를 만들고, 이는 비선택성 이온통로가 되어 세포의 삼투압 교란을 일으켜 세포를 사멸시킨다[4].

톨라신의 세포독성은 세포의 원형질막에 pore를 형성하는 특 성을 이용하여 쥐의 적혈구를 이용한 용혈활성으로 빠르게 측 정하는 방법이 널리 쓰인다. 톨라신의 이온통로 형성 및 세포 파괴는 $\mathrm{Hg}^{2+}, \mathrm{Cd}^{2+}$ 과 같은 중금속 이온과 $\mathrm{Zn}^{2+}$ 와 $\mathrm{Ni}^{2+}$ 등 2 가 양이온에 의해 저해됨이 확인되었고, 각 성분의 작용기작이 확 인 또는 제안되었다[5,6]. Gadolinium은 원자번호 64번의 Lanthanide이며 수용액에서 3가 양이온으로 존재한다. 이온반지 름은 $0.938 \AA$ 으로 $\mathrm{Zn}^{2+}(0.74 \AA)$ 와 $\mathrm{Ni}^{2+}(0.69 \AA)$ 보다 크다. $\mathrm{Gd}^{3+}$ 은 물리적인 자극에 의해 활성화된 MSC (mechanosensitive ion channel)를 저해함이 보고되었으나 작용기작은 명확하게 밝 혀지지 않았다. Millet과 Pickard[7]는 식물에서 최초로 $\mathrm{Gd}^{3+}$ 의 $\mathrm{MSC}$ 차단효과를 확인하였으며, 전기생리학적 연구를 통하여 식 물뿐만 아니라, 곰팡이[8], 박테리아[9], 동물세포[10,11]에서도 억제 효과가 관찰되었다. Yang과 Sachs의 연구[12]는 Xenopus oocytes에서 $\mathrm{Gd}^{3+}$ 이 $\mathrm{MSC}$ 를 세포 바깥쪽에서 완전히 가역적으 로 차단한다고 보고하였다. $\mathrm{MSC}$ 의 저해는 $1-100 \mu \mathrm{M} \mathrm{Gd}^{3+}$ 농 
도 범위에서 일어났다[13]. $\mathrm{MSC}$ 저해에 관련된 $\mathrm{Gd}^{3+}$ 의 작용기 작은 정확히 밝혀지지 않았으나, Lanthanides는 지질막이중층의 음 으로 하전된 인지질 등과 강하게 결합하며[14], 막의 상전이 온도 를 높이고, 지질막의 유동성을 감소시키는 것이 밝혀졌다 $[15,16]$. $\mathrm{Gd}^{3+}$ 은 수용액에서 다양한 음이온과 결합할 수 있으므로 $\mathrm{Gd}^{3+}$ 농도에 영향을 줄 수 있는 phosphate와 sulfate, bicarbonate 등 의 성분이 용액에 포함되지 않아야 하며, HEPES나 MOPS, PIPES의 완충액을 사용한다[17]. $\mathrm{Gd}^{3+}$ 은 다양한 이온통로에 영 향을 주는 것으로 밝혀져, L-형과 $\mathrm{T}$-형 $\mathrm{Ca}^{2+}$ 이온통로[18], 막 전위 의존성 $\mathrm{K}^{+}$과 $\mathrm{Na}^{+}$이온통로 등에서 저해효과가 보고되었 다[19]. 그러나 톨라신과 같은 세포막 pore-형성 펩티드에 의해 생성된 이온통로와 $\mathrm{Gd}^{3+}$ 과의 상호연관은 국제적으로 보고되지 않았으며, 세포막에서 $\mathrm{Gd}^{3+}$ 에 의한 이온통로 억제 기작 또한 완 전히 밝혀지지 않은 상태이므로 이에 대한 연구가 필요하다. 본 연구에서는 톨라신 펩티드 독소의 갈반병 발생기작을 연구하던 중, $\mathrm{Gd}^{3+}$ 이 적혈구 막에 생성된 톨라신 이온통로를 저해하여 용 혈활성을 억제함을 발견하였고, 이에 대한 특성을 조사하였다.

\section{재료 및 방법}

\section{톨라신의 분리}

P. tolaasii 6264 균주를 Pseudomonas agar $\mathrm{F}\left(\mathrm{MgSO}_{4} \cdot 7 \mathrm{H}_{2} \mathrm{O}\right.$ $1.5 \mathrm{~g}, \mathrm{~K}_{2} \mathrm{HPO}_{4} \cdot 3 \mathrm{H}_{2} \mathrm{O} 1.5 \mathrm{~g}$, Bacto-peptone $10 \mathrm{~g}$, Bacto-tryptone $10 \mathrm{~g}$, glycerol $10 \mathrm{~mL}$ per liter) 액체 배지에 접종하여 배양한 후, 균체가 제거된 배양상징액에 $30 \%$ 의 ammonium sulfate를 가하고 $4{ }^{\circ} \mathrm{C}$ 에서 정치한 후, $20,000 \mathrm{rpm}(50,000 \times \mathrm{g})$ 에서 1 시간 동안 초원심분리하여 crude 톨라신을 얻었고, 이를 순수분리에 사용하였다. 톨라신의 순수분리는 Cho 등[20]의 방법에 따라 수 행하였으며, gel permeation chromatography와 HPLC를 이용하 여 분석하였다.

\section{버섯조직함몰검정법(Pitting test)}

양송이버섯을 이용하여 P. tolaasii 6264 균주의 갈반형성능을 확인하였다. 먼저 양송이버섯의 자실체를 수평으로 절단한 면에 균주배양액을 $5 \mu \mathrm{L}$ 점적하여 흡수시킨 후, 습도가 유지되도록 장치한 square dish에 담아 밀봉하였다. $25^{\circ} \mathrm{C}$ 에서 12-24시간 동 안 배양하면서 점적부위의 변색 및 함몰 정도를 관찰하였다.

\section{용혈활성 측정}

P. tolaasii 6264 균주의 세포독성을 측정하기 위하여 쥐의 적혈 구를 이용하였다. 용혈활성 측정에 사용한 적혈구는 사용 직전 에 HEPES-buffered saline $(150 \mathrm{mM} \mathrm{NaCl}, 5 \mathrm{mM} \mathrm{KCl}, 5 \mathrm{mM}$ $\mathrm{HEPES}, 1 \mathrm{mM} \mathrm{MgSO} 4, \mathrm{pH}$ 7.4) 용액으로 10 배 희석하였고, 이것을 최종 반응 용액에 $10 \%$ 가 되도록 처리하였다. 용혈활성 측정시 $37^{\circ} \mathrm{C}$ 에서 $1 \%$ 의 적혈구를 30 분 이내에 모두 용혈시키 는 톨라신의 농도를 1 hemolytic unit $(\mathrm{HU})$ 로 정하여 사용하였 다. 용혈활성은 UV/vis spectrophotometer (U-2000, Hitachi, Tokyo)를 사용하여 $600 \mathrm{~nm}$ 에서 흡광도 변화로 측정하였다. $\mathrm{Zn}^{2+}$ 와 $\mathrm{Ni}^{2+}, \mathrm{Mg}^{2+}, \mathrm{Al}^{3+}$ 은 HEPES buffer에 용해하였으며, $\mathrm{Gd}^{3+}$ 은 음이온에 의한 영향을 막기 위하여[17] 증류수에 녹여 최종반 응용액의 $10 \%$ 가 되도록 첨가하여 측정하였다.

\section{결과 및 고찰}

\section{다가 양이온에 의한 용혈활성 저해}

양이온에 의한 톨라신의 용혈활성 변화를 확인하기 위하여, 다 양한 2가 $\left(\mathrm{Zn}^{2+}, \mathrm{Ni}^{2+}, \mathrm{Mg}^{2+}\right)$ 및 3 가 $\left(\mathrm{Al}^{3+}, \mathrm{Gd}^{3+}\right)$ 양이온을 적혈 구 용액에 처리하여 용혈활성을 측정하였다(Fig. 1). 각각의 양 이온들의 처리농도는 모두 $10 \mathrm{mM}$ 로 동일하게 하였으며, $37^{\circ} \mathrm{C}$ 에서 30 분간 배양한 후 적혈구 파괴에 따른 흡광도 변화를 측 정하였다. 기존 연구에서 보고된 2가 양이온인 $\mathrm{Zn}^{2+}$ 와 $\mathrm{Ni}^{2+}$, $\mathrm{Mg}^{2+}$ 은 톨라신에 의한 용혈을 억제하며, 이것은 Cho 등[5]의 결과와 일치하였다. $\mathrm{Zn}^{2+}$ 는 용혈활성을 완벽하게 저해하였으며, $\mathrm{Ni}^{2+}$ 과 $\mathrm{Mg}^{2+}$ 은 이 농도에서 $50 \%$ 전후의 용혈억제 효과를 보였 다. 특히, 3 가 양이온인 $\mathrm{Al}^{3+}$ 과 $\mathrm{Gd}^{3+}$ 은 톨라신의 용혈활성을 $90 \%$ 이상 저해하는 것으로 관측되었으나, $\mathrm{Al}^{3+}$ 은 용액자체의 흡 광도로 인해 용혈에 의한 흡광도 변화를 측정하기 어렵게 만들 어 정량적인 용혈활성 측정이 어려웠다.

톨라신의 용혈활성에 대한 $\mathrm{Gd}^{3+}$ 의 효과는 보고된 바가 없어, 이를 확인하기 위하여 $100 \mu \mathrm{M}$ 에서 $10 \mathrm{mM}$ 까지 $\mathrm{Gd}^{3+}$ 의 농도를 증가시키며 톨라신의 용혈활성 변화를 측정하였다. 먼저, 적혈 구와 $\mathrm{Gd}^{3+}$ 만 처리한 대조실험에서 $\mathrm{Gd}^{3+}$ 은 $1 \mu \mathrm{M}-100 \mathrm{mM}$ 의 농 도에서 적혈구에 영향을 주지 않았다(자료미제시). 반면 톨라신 과 적혈구, $\mathrm{Gd}^{3+}$ 을 함께 처리한 경우, $\mathrm{Gd}^{3+}$ 의 농도가 비교적 낮 은 $100 \mu \mathrm{M}$ 에선 용혈활성이 $\mathrm{Gd}^{3+}$ 을 포함하지 않은 대조활성보 다 약간 증가하여 용혈이 빠르게 진행되었고, $\mathrm{Gd}^{3+}$ 의 농도가 증 가할수록 톨라신에 의한 용혈이 늦어져 톨라신의 활성이 점진 적으로 저해되었다(Fig. $2 \mathrm{~A}$ ). $\mathrm{Gd}^{3+}$ 의 저해효과는 $200 \mu \mathrm{M}$ 이상 의 농도에서 나타나기 시작하여 $1 \mathrm{mM}$ 이상에선 톨라신의 세포 독성을 완전히 저해하였다. 톨라신에 의한 용혈활성을 $50 \%$ 저 해시키는 농도인 $\mathrm{K}_{\mathrm{i}}$ 값은 약 $250 \mu \mathrm{M}$ 로 측정되었다(Fig. $2 \mathrm{~B}$ ).

\section{$\mathbf{G d}^{3+}$ 에 의한 버섯 갈반형성 저해}

버섯조직에서 $\mathrm{Gd}^{3+}$ 에 의한 톨라신의 버섯세포독성 저해효과를

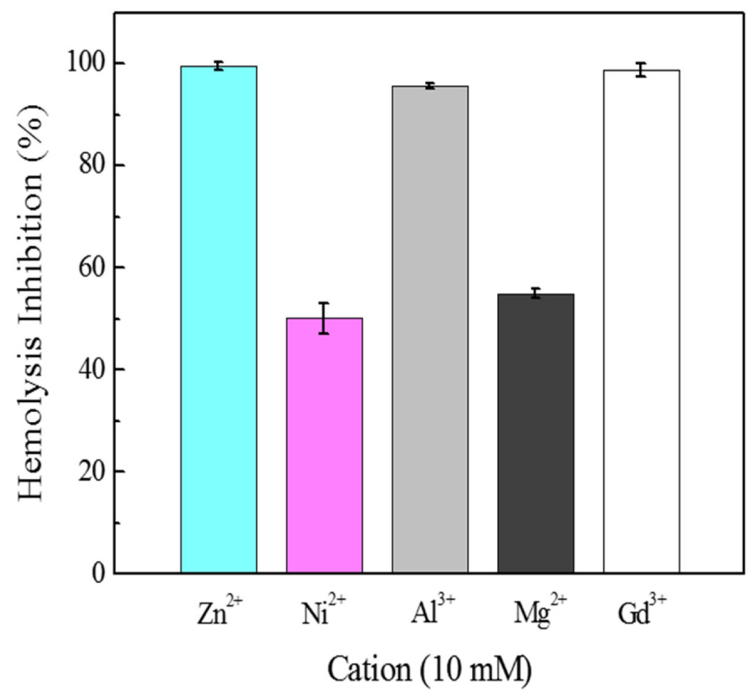

Fig. 1 Inhibition of tolaasin-induced hemolysis by various multivalent cations. Hemolysis was induced by tolaasin. Inhibitions of hemolysis were measured with cations $\left(\mathrm{Zn}^{2+}, \mathrm{Ni}^{2+}, \mathrm{Al}^{3+}, \mathrm{Mg}^{2+}, \mathrm{Gd}^{3+}\right)$ at $10 \mathrm{mM}$ 

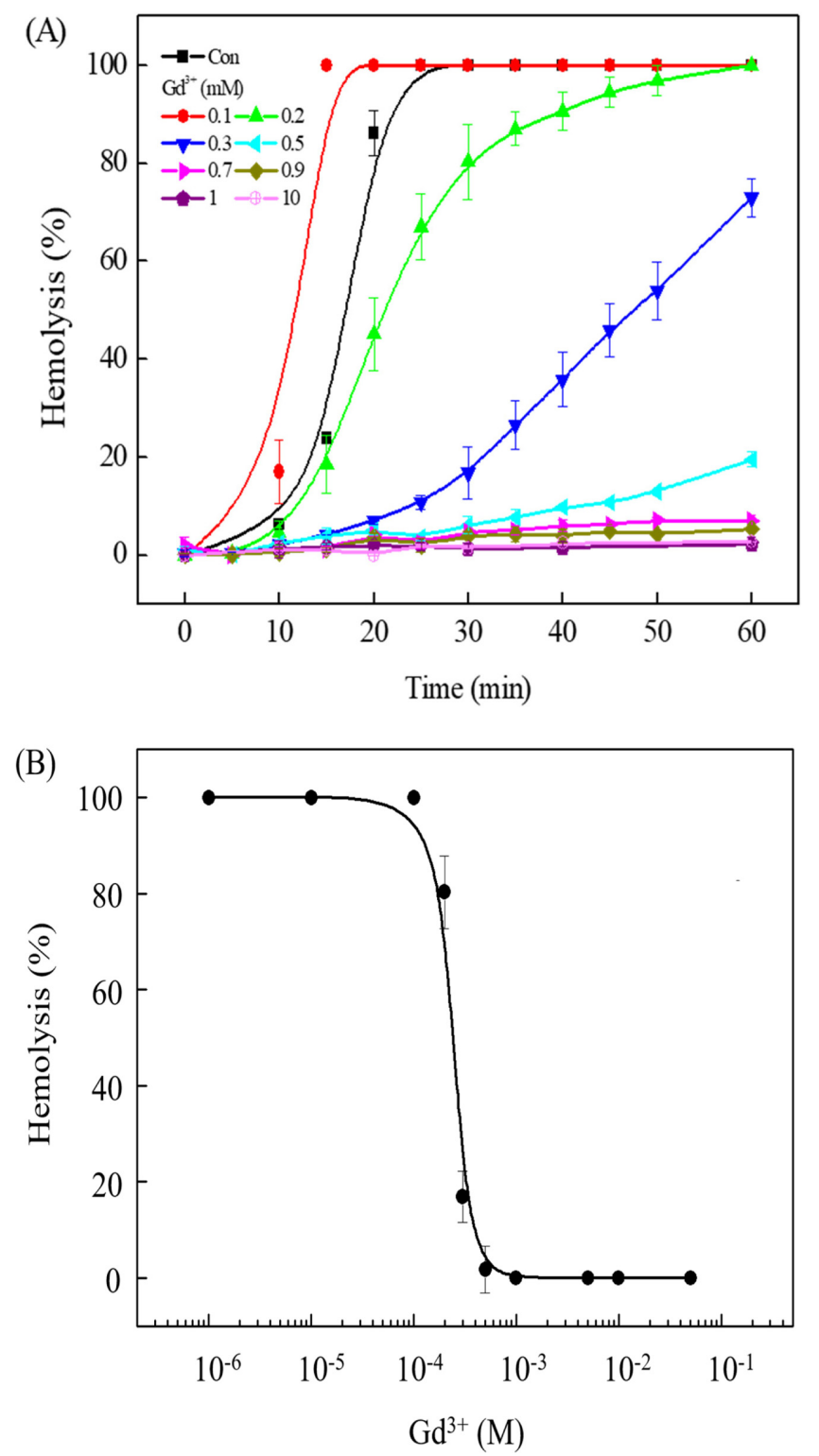

Fig. 2 Effect of $\mathrm{Gd}^{3+}$ on tolaasin-induced hemolysis. (A) Effects of $\mathrm{Gd}^{3+}$ at the concentrations from $100 \mu \mathrm{M}$ to $10 \mathrm{mM}$. (B) Dose response curve of $\mathrm{Gd}^{3+}$ on the inhibition of tolaasin-induced hemolysis

확인하였다(Fig. 3). 양송이버섯의 자실체 조직 절단면에 0.1-5 $\mathrm{mM}$ 의 $\mathrm{Gd}^{3+}$ 만을 처리하였을 경우에는 절단된 갓 표면에서 조 직의 함몰이나 색 변화는 나타나지 않았다(Fig. 3A). 그러나, 톨 라신만을 절단면에 처리하였을 때에는 갈반현상과 버섯조직의 함몰이 발생하였다. 톨라신과 $\mathrm{Gd}^{3+}$ 을 혼합하여 처리한 경우에 는 버섯 절단면에 갈색 반점의 발생이 약해지거나 나타나지 않 았다. 먼저, $1 \mathrm{mM}$ 농도의 $\mathrm{Gd}^{3+}$ 을 처리한 경우에 갈반 발생이 약화되었으며, $5 \mathrm{mM}$ 의 $\mathrm{Gd}^{3+}$ 처리시에는 갈반형성이 크게 억제 되는 것을 확인하였다(Fig. 3B).

버섯 조직을 이용한 실험에서 톨라신에 의한 세포독성은 $\mathrm{Gd}^{3+}$ 의 농도 증가에 따라 점차 저해되어 용량의존형 저해를 보였다. 적혈구와 양송이 버섯에서 $\mathrm{Gd}^{3+}$ 에 의한 톨라신의 세포독성 저
(A)

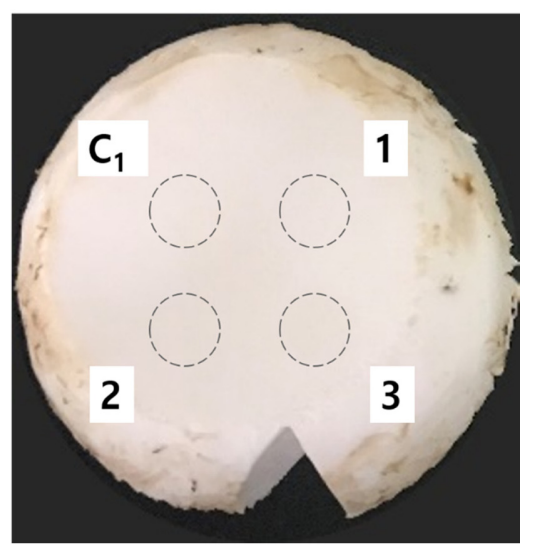

(B)

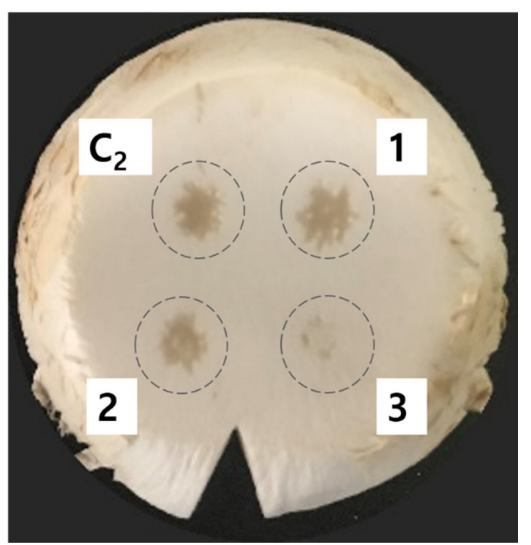

Fig. 3 Inhibition of tolaasin-induced blotch formation by $\mathrm{Gd}^{3+}$. (A) Effect of $\mathrm{Gd}^{3+}$ only. $\mathrm{C}_{1}$ : culture media. (B) Tolaasin-induced blotch formation in the presence of various concentrations of $\mathrm{Gd}^{3+}$. $\mathrm{C}_{2}$ : tolaasin, $1: 0.1 \mathrm{mM}$ $\mathrm{Gd}^{3+}, 2: 1 \mathrm{mM} \mathrm{Gd}^{3+}, 3: 5 \mathrm{mM} \mathrm{Gd}^{3+}$

해효과는 각각 $0.7 \mathrm{mM}$ 과 $5 \mathrm{mM}$ 농도에서 나타나, 세포독성 측 정 대상에 따라 저해효과를 보이는 $\mathrm{Gd}^{3+}$ 의 농도는 차이를 보였 다. 이러한 차이는 적혈구와 조직 간의 차이에 기인할 수 있다. 적혈구의 경우에는 반응용액에 첨가시 적혈구 세포막이 톨라신 및 $\mathrm{Gd}^{3+}$ 등 첨가물에 즉시 노출되어 반응하기 때문에 낮은 농 도에서 $\mathrm{Gd}^{3+}$ 의 저해효과가 나타났다. 그러나, 버섯 등의 균류 (fungi)는 glycoproteins 및 glucans, polysaccharides, chitosan 등 다양한 성분들이 세포막 외부에 있어[21] 톨라신 및 $\mathrm{Gd}^{3+}$ 이 세포막에 작용하기 위해서는 보다 높은 농도가 필요할 것으로 판단된다. 버섯의 세포벽 등을 제거한 원형질체를 얻어 톨라신 의 세포독성을 측정한다면 이러한 농도차이를 줄일 수 있을 것 이다.

\section{$\mathrm{Gd}^{3+}$ 과 $\mathrm{Zn}^{2+}$ 에 의한 용혈활성 저해비교}

톨라신에 의한 용혈작용은 적혈구 막에 톨라신 분자의 유입, 막 에서의 다중체 형성을 통한 pore 형성, 그리고 형성된 pore를 통한 이온의 확산이동으로 삼투압의 교란에 의해 이루어짐이 알 려져 있다[4]. $\mathrm{Gd}^{3+}$ 에 의한 톨라신의 용혈활성 저해 기작을 알 아보기 위해 $\mathrm{Gd}^{3+}$ 결합의 가역성을 $\mathrm{EDTA}$ 를 이용하여 측정하였 다. 적혈구와 EDTA만 처리한 대조실험에서 $0.5-10 \mathrm{mM}$ 의 $\mathrm{EDTA}$ 는 적혈구의 용혈작용에 영향을 미치지 않았으며(자료미 


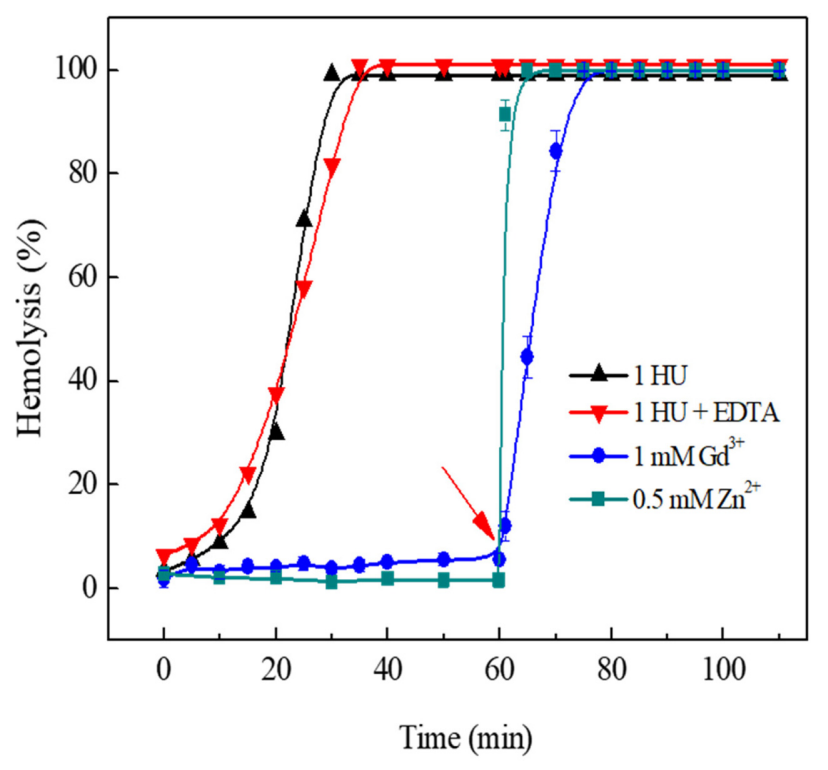

Fig. 4 Reversible effect of $\mathrm{Gd}^{3+}$ and $\mathrm{Zn}^{2+}$ on tolaasin-induced hemolysis. Hemolyses were induced with $1 \mathrm{HU}$ tolaasin, tolaasin plus EDTA, tolaasin plus $1 \mathrm{mM} \mathrm{Gd}^{3+}$, and tolaasin plus $0.5 \mathrm{mM} \mathrm{Zn}^{2+}$. In the experiments with $\mathrm{Zn}^{2+}$ and $\mathrm{Gd}^{3+}$, EDTA was added after $60 \min (\searrow)$ inhibition

제시), 톨라신 $1 \mathrm{HU}$ 와 $\mathrm{EDTA}$ 를 함께 처리한 경우에도 30 분 이 내에 완전한 용혈이 일어나 EDTA 만의 효과는 없었다. 그러나, $1 \mathrm{mM} \mathrm{Gd} d^{3+}$ 과 $500 \mu \mathrm{M} \mathrm{Zn^{2+ }}$ 처리 시에는 톨라신에 의한 용혈이 완전히 저해되었으며, 여기에 $\mathrm{EDTA}$ 를 추가하여 처리할 경우 $\mathrm{Gd}^{3+}$ 과 $\mathrm{Zn}^{2+}$ 이온이 제거되며 톨라신에 의한 용혈효과는 즉시 나타났다. $\mathrm{Zn}^{2+}$ 와 $\mathrm{Gd}^{3+}$ 에 의해 용혈이 저해된 상태에서 60 분이 경과한 후, $1 \mathrm{mM}$ 의 $\mathrm{EDTA}$ 를 첨가했을 때(Fig. 4, 표시), $\mathrm{Zn}^{2+}$ 와 $\mathrm{Gd}^{3+}$ 처리구 모두 용혈이 나타났다. EDTA에 의한 $\mathrm{Zn}^{2+}$ 의 제거 시에는 빠른 용혈활성을 보이며 $100 \%$ 의 용혈이 약 2 분 이내에 관측되었다. 그러나 $\mathrm{Gd}^{3+}$ 의 처리구 에서는 $100 \%$ 용 혈이 약 10 분이 소요되었다. EDTA에 의한 $\mathrm{Zn}^{2+}$ 와 $\mathrm{Gd}^{3+}$ 의 제 거 후 톨라신에 의한 용혈활성회복의 시간적 차이는 이 두 양 이온의 톨라신 저해 기작이 다름을 보여준다. $\mathrm{Zn}^{2+}$ 는 톨라신이 적혈구 세포막에 pore를 형성한 후 이온통로를 막는 plugging 효과에 의함이 보고되었다[5]. 그러나, $\mathrm{Gd}^{3+}$ 처리구 에서는 용 혈활성회복 속도가 느리게 일어났고 이것은 $\mathrm{Gd}^{3+}$ 에 의한 용혈 활성 저해기작이 $\mathrm{Zn}^{2+}$ 와는 다름을 보여준다.

\section{$\mathbf{G d}^{3+}$ 과 $\mathbf{Z n}^{2+}$ 의 톨라신 용혈활성 저해특성}

$\mathrm{EDTA}$ 를 이용한 금속이온의 가역적 저해여부 확인 실험에서 $\mathrm{EDTA}$ 로 $\mathrm{Gd}^{3+}$ 과 $\mathrm{Zn}^{2+}$ 를 제거하면 $\mathrm{Zn}^{2+}$ 처리구에서는 즉시 용혈 이 일어났으나, $\mathrm{Gd}^{3+}$ 처리구에서는 $\mathrm{Zn}^{2+}$ 과 비교하여 느리게 용 혈이 나타났다. 이는 $\mathrm{Gd}^{3+}$ 과 $\mathrm{Zn}^{2+}$ 가 톨라신의 용혈활성을 서로 다른 기작을 통해 저해할 가능성을 보여주는 것으로, 용혈저해 특성을 PEG 2000을 이용하여 조사하였다. 톨라신의 용혈활성 은 삼투억제제인 PEG 2000 (polyethyleneglycol 2000)의 처리 에 의해 억제될 수 있다. 톨라신을 처리한 적혈구에 PEG 2000 을 가하면 톨라신에 의해 pore가 형성되어 있음에도 외부의 높
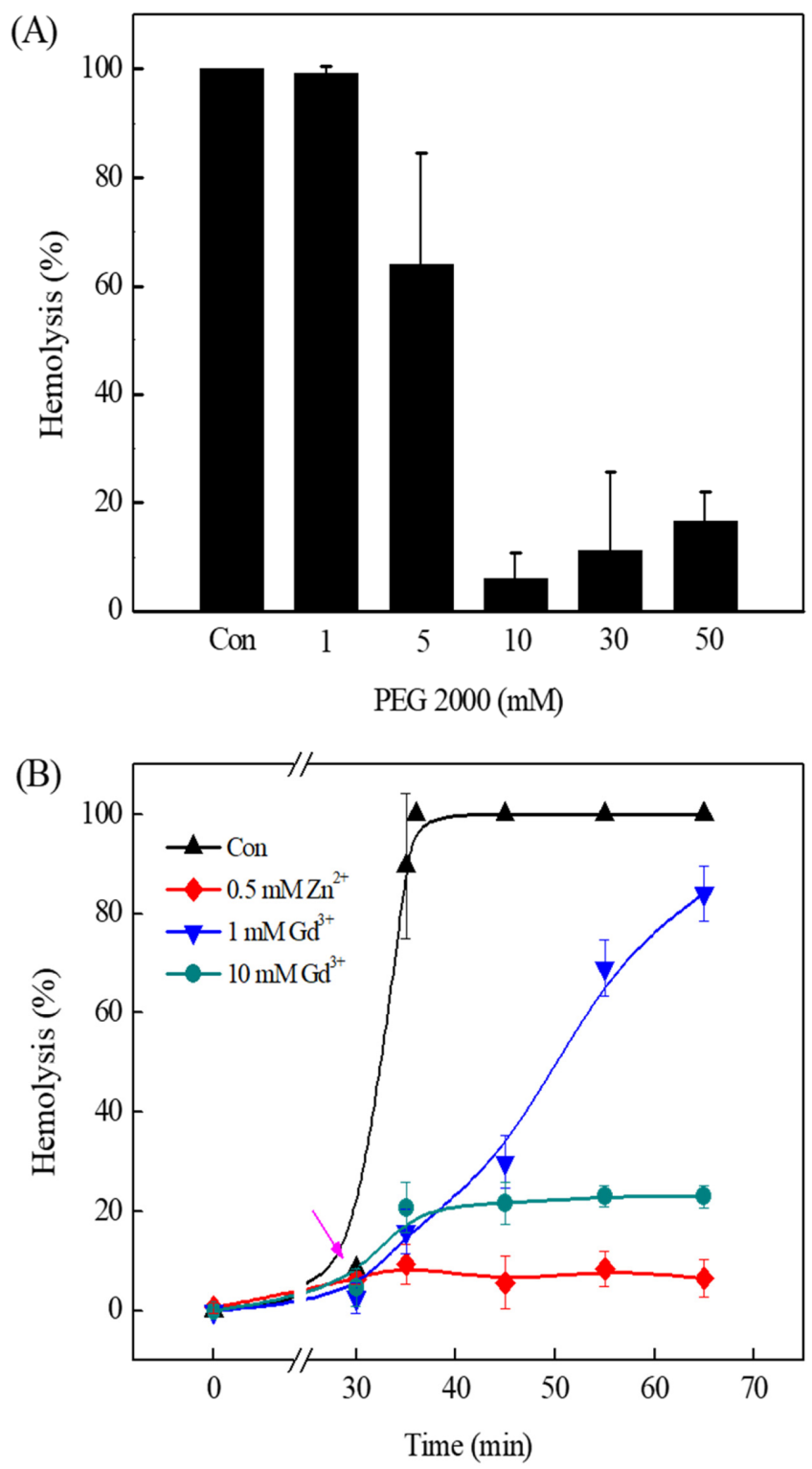

Fig. 5 Inhibition of pre-formed tolaasin channel by $\mathrm{Gd}^{3+}$ and $\mathrm{Zn}^{2+}$. (A) Dose-dependent inhibitions of tolaasin-induced hemolysis by PEG 2000. (B) Tolaasin was added in the presence of PEG 2000. After removal of PEG 2000 at $30 \mathrm{~min}$ by centrifugation, RBCs were resuspended in the solution containing the indicated concentrations of $\mathrm{Gd}^{3+}$ and $\mathrm{Zn}^{2+}$

은 삼투압으로 적혈구 세포는 파괴되지 않고 보호된다[22].

$\mathrm{Gd}^{3+}$ 과 $\mathrm{Zn}^{2+}$ 의 작용 특성을 확인하기 위해, 먼저 PEG 2000 의 농도에 따른 톨라신의 용혈활성 저해효과를 측정하였다. PEG 2000 은 $10 \mathrm{mM}$ 에서 톨라신에 의한 용혈을 $6 \%$ 이내로 억제하였 다(Fig. $5 \mathrm{~A}$ ). 이는 적혈구 막에 톨라신에 의한 이온통로가 10 분 이내에 형성되지만 삼투억제제(osmotic protectant)로 작용하는 PEG 2000에 의해 세포외부의 삼투압 유지로 30 분이 경과하여 도 용혈이 일어나지 않는 상태가 유지됨을 보여준다. 이 때, 원 심분리를 통해 적혈구를 침전 시킨 후, 상징액에 포함된 $\mathrm{PEG}$ 2000 을 제거하고 새로운 HEPES 완충액으로 침전된 적혈구를 
현탁시키면, 5 분 이내에 완전한 용혈활성이 관찰되었다(Fig. $5 \mathrm{~B}$ ). 이는 PEG 2000이 새로 형성되는 톨라신의 이온통로에 영향을 주지 않으며 세포를 보호함을 보여준다. 같은 방법으로 원심분 리를 통해 PEG 2000을 제거한 후, 톨라신이 처리된 적혈구를 $\mathrm{Gd}^{3+}$ 과 $\mathrm{Zn}^{2+}$ 를 함유한 $\mathrm{HEPES}$ 완충액에 현탁시켰을 때, $\mathrm{Zn}^{2+}$ 의 경우 용혈활성을 즉시 억제하였다. 반면, $\mathrm{Gd}^{3+}$ 은 $1 \mathrm{mM}$ 농도에 서 용혈이 완만하게 나타났으며, $10 \mathrm{mM}$ 농도에서는 $20 \%$ 의 용 혈이 느리게 일어났다.

$\mathrm{Zn}^{2+}$ 의 빠른 저해효과는 이전의 연구[5]에서 밝혔듯이 $\mathrm{Zn}^{2+}$ 가 톨라신의 이온통로 형성과정을 저해하지 않으나, 형성된 통로를 물리적으로 막아 톨라신의 용혈활성을 저해함을 보여준다. PEG 2000에 의해 용혈이 억제된 상태에서 PEG 2000을 제거하면 이 미 형성된 톨라신 pore에 의해 5 분 이내에 용혈이 나타나며, 여 기에 $\mathrm{Zn}^{2+}$ 를 가하면 톨라신 pore가 즉시 저해됨으로 용혈은 완 전히 억제되는 것이다(Fig. $5 \mathrm{~B}$ ). 동일한 조건에서 $\mathrm{Gd}^{3+}$ 의 경우 는 이미 생성된 톨라신 pore를 저해하였으나, $\mathrm{Zn}^{2+}$ 와 같이 물리 적으로 pore를 막음으로써 일어나는 것이 아닌 다른 기작에 의 해 톨라신의 활성을 억제함을 보여준다. $\mathrm{Gd}^{3+}$ 은 물리적 자극에 의해 활성화되는 $\mathrm{MSC}$ 의 저해에서 밝혀진 것처럼[23] 다가양이 온이 세포막 인지질 등의 음이온과 결합하여 톨라신 채널의 분 자다중체의 안정성에 영향을 줌으로써 활성을 저해하는 것으로 사료된다. $\mathrm{Gd}^{3+}$ 과 막지질, 톨라신의 상호작용을 밝히면 톨라신 분자의 다중체 결합 및 이에 따른 이온통로의 형성기작 연구에 크게 기여할 것이다.

\section{초록}

느타리버섯의 갈반병은 Pseudomonas tolaasii에 의해 생성된 톨 라신 및 이의 유사 펩티드 독소에 의해 발생한다. 톨라신 펩티 드들은 세포막에 pore를 형성하고 버섯의 자실체 구조를 파괴 한다. 적혈구가 파괴되는 용혈은 톨라신의 세포독성에 의해 일 어난다. 톨라신의 용혈활성은 $\mathrm{Zn}^{2+}$ 및 $\mathrm{Ni}^{2+}$ 과 같은 금속 이온에 의해 저해된다. 가돌리니움 이온을 첨가하였을 때, 톨라신에 의 한 용혈작용에서 $1 \mathrm{mM}$ 이하의 농도에서는 용혈작용이 증가하 고 그 이상의 농도에서는 저해되는 이중 효과가 나타났다. 가 돌리니움 이온에 의한 톨라신 활성저해 기작은 다른 양이온들 에 의한 저해기작과 다른 것으로 보인다. 가돌리니움 이온은 음 전하를 갖는 막지질들에 결합하여 지질막의 측압을 변화시키는 것으로 보고되어, 톨라신 이온통로의 여닫힘에 직접 작용하기 보다는 막 구조의 단단함을 증가시켜 막에 대한 톨라신 이온통 로의 안정성을 감소시키는 것으로 보인다.

Keywords 가돌리니움 - 막 유동성 · 슈도모나스 톨라시 · 톨라신

감사의 글 이 논문은 2017 년도 정부(교육부)의 재원으로 한국연구재단의 지원을 받아 수행된 기초연구사업임(No. 2017R1D1A3B03032718).

\section{References}

1. Bellettini MB, Fiorda FA, Maieves HA, Teixeira GL, Avila S, Hornung PS, Juinor AM, Ribani RH (2016) Factors affecting mushroom Pleurotus spp. Saudi J Biol Sci 26: 633-646. doi: 10.1016/j.sjbs.2016.12.005

2. Gonzalez A, Gonzalez-Varela G, Gea F (2009) Brown blotch caused by Pseudomonas tolaasii on cultivated Pleurotus eryngii in Spain. Plant Dis 93: 667. doi: 10.1094/PDIS-93-6-0667B

3. Han HS, Jhune CS, Cheong JC, Oh JA, Kong WS, Cha JS, Lee CJ (2012) Occurrence of black rot of cultivated mushrooms (Flammulina velutipes) caused by Pseudomonas tolaasii in Korea. Eur J Plant Pathol 133: 527-535

4. Cho KH, Kim YK (2003) Two types of ion channel formation of tolaasin, a Pseudomonas peptide toxin. FEMS Microbiol Lett 221: 221226. doi: 10.1016/S0378-1097(03)00182-4

5. Cho KH, Kim ST, Kim YK (2006) Inhibitory effect of $\mathrm{Zn}^{2+}$ on tolaasininduced hemolysis. J Appl Biol Chem 49: 281-286

6. Choi TK, Wang HS, Kim YK (2009) Inhibitory effect of $\mathrm{Ni}^{2+}$ on the tolaasin-induced hemolysis. J Appl Biol Chem 52: 28-32. doi: 10.3839/ jabc. 2009.005

7. Millet B, Pickard BG (1988) Gadolinium ion is an inhibitor suitable for testing the putative role of stretch-activated ion channels in geotropism and thigmotropism. Biophys J 53: 115a

8. Zhou XL, Stumpf MA, Hoch HC, Kung C (1991) A mechanosensitive channel in whole cells and in membrane patches of the fungus Uromyces. Science 253: 1415-1417. doi: 10.1126/science.1716786

9. Dedkova K, Kuznikova L, Pavelek L, Matejova K, Kupkova J, Cech Barabaszova K, Vana R, Burda J, Vlcek J, Cvejn D, Kukutschova J (2017) Daylight induced antibacterial activity of gadolinium oxide, samarium oxide and erbium oxide nanoparticles and their aquatic toxicity. Mater Chem Phys 197: 226-235. doi: 10.1016/j.matchemphys. 2017.05.039

10. Zandieh A, Payabvash S, Pasalar P, Morteza A, Zandieh B, Tavangar SM, Dehpour AR (2011) Gadolinium chloride, a Kupffer cell inhibitor, attenuates hepatic injury in a rat model of chronic cholestasis. Hum Exp Toxicol 30: 1804-1810. doi: 10.1177/0960327111400106

11. Jones C, Badger SA, Hoper M, Parks RW, Diamond T, Taylor MA (2013) Hepatic cytokine response can be modulated using the Kupffer cell blocker gadolinium chloride in obstructive jaundice. Int J Surg 11: 46-51. doi: 10.1016/j.ijsu.2012.11.008

12. Yang XC, Sachs F (1989) Block of stretch-activated ion channels in Xenopus oocytes by gadolinium and calcium ions. Science 243:10681071. doi: 10.1126/science. 2466333

13. Zhang H, Walcott GP, Rogers JM (2018) Effects of gadolinium on cardiac mechanosensitivity in whole isolated swine hearts. Sci Rep 8: 10506

14. Lehrmann R, Seelig J (1994) Adsorption of $\mathrm{Ca}^{2+}$ and $\mathrm{La}^{3+}$ to bilayer membranes: measurement of the adsorption enthalpy and binding constant with titration calorimetry. Biochim Biophys Acta 1189: 89-95. doi: 10.1016/0005-2736(94)90284-4

15. Li X, Zhang Y, Ni J, Chen J, Hwang F (1994) Effect of lanthanide ions on the phase behavior of dipalmitoylphosphatidylcholine multilamellar liposomes. J Inorg Biochem 53: 139-149. doi: 10.1016/0162-0134(94) 85028-3

16. Yu A, Ermakov AZ, Averbakh VI, Lobyshev VI, Sukharev SI (1996) Effects of gadolinium on electrostatic and thermodynamic properties of lipid membranes. Biophys J 70: A96

17. Caldwell RA, Clemo HF, Baumgarten CM (1998) Using gadolinium to identify stretch-activated channels: Technical considerations. Am J Physiol 275: C619-621. doi: 10.1152/ajpcell.1998.275.2.C619

18. Sutresno A, Haryanto F, Viridi S, Arif I (2020) Influence blocking by gadolinium in calcium diffusion on synapse model: A monte carlo simulation study. J Biomed Phys Eng 10: 251-260. doi: 10.31661/ jbpe.v0i0.1155

19. Elinder F, Arhem P (1994) Effects of gadolinium on ion channels in the myelinated axon of Xenopus laevis: Four sites of action. Biophys J 67: 71-83. doi: 10.1016/S0006-3495(94)80456-4

20. Cho KH, Kim ST, Kim YK (2007) Purification of a pore-forming peptide toxin, tolaasin, produced by Pseudomonas tolaasii 6264. J 
Biochem Mol Biol 40: 113-118. doi: 10.5483/BMBRep.2007.40.1.113

21. Gow NAR, Latge JP, Munro CA (2017) The fungal cell wall: Structure, biosynthesis, and function. Microbiol Spectrum 5: FUNK-0035-2016. doi: 10.1128/microbiolspec.FUNK-0035-2016

22. Wei S, Chi T, Meng A, Chen C, An T, Wang M, Zhang Y (2013)

Characteristics of hemolytic activity induced by skin secretions of the frog Kaloula pulchra hainana. J Venom Anim Toxins Incl Trop Dis 9: 9 23. Hajduczok G, Chapleau MW, Ferlic RJ, Mao HZ, Abboud FM (1994) Gadolinium inhibits mechanoelectrical transduction in rabbit carotid baroreceptors. Implication of stretch-activated channels. J Clin Invest 94: 2392-2396 